\title{
PENGARUH EKSTRAK GULMA SIAM, KEMUNING DAN SALIARA TERHADAP PENGHAMBATAN PERTUMBUHAN BAKTERI LAYU PISANG SECARA IN VITRO
}

\author{
Nova Adelina Lubis, Titik Nur Aeny, Joko Prasetyo \& Radix Suharjo \\ Jurusan Agroteknologi, Fakultas Pertanian Universitas Lampung \\ Jl. Prof. Soemantri Brodjonegoro, No.1, Bandar Lampung 35145 \\ E-mail: adelina.nova27@gmail.com
}

\begin{abstract}
ABSTRAK
Salah satu penyakit penting pada tanaman pisang adalah penyakit layu bakteri, yang disebabkan oleh Blood Disease Bacterium (BDB). Beberapa jenis tanaman telah dilaporkan mengandung senyawa antibakteri yang dapat menjadi alternatif pengendalian penyakit tanaman yang disebabkan oleh bakteri. Penelitian ini bertujuan untuk mengetahui pengaruh ekstrak Chromolaena odorata, Murraya paniculata dan Lantana camara terhadap penghambatan perrtumbuhan BDB secara in vitro. Penelitian dilakukan di Laboratorium Bioteknologi Fakultas Pertanian Universitas Lampung pada Maret hingga Juli 2016. Perlakuan disusun menggunakan Rancangan Acak Lengkap dalam faktorial. Faktor pertama adalah lama perendaman bahan tanaman sebelum diekstrak dan faktor kedua adalah tingkat konsentrasi ekstrak. Pengamatan dilakukan terhadap diameter zona penghambatan pada 24 jam setelah aplikasi. Data diuji dengan analisis ragam dan nilai tengah antar perlakuan diuji dengan uji Beda Nyata Terkecil (BNT) pada taraf 5\%. Hasil penelitian menunjukkan bahwa pada perlakuan ekstrak kemuning, interaksi antara lama perendaman dan tingkat konsentrasi berpengaruh nyata terhadap diameter zona penghambatan BDB sedangkan pada ekstrak gulma siam dan saliara interaksinya tidak nyata. Diameter zona penghambatan paling tinggi ekstrak gulma siam, kemuning dan saliara dalam menghambat pertumbuhan BDB secara berurutan adalah $85 \%, 55 \%$ dan $95 \%$.
\end{abstract}

Kata kunci: Blood Disease Bacterium, Chromolaena odorata, ekstrak, konsentrasi, Lantana camara, Murraya paniculata, penghambatan

\section{PENDAHULUAN}

Pisang (Musa paradisiaca L.) adalah tanaman buah berupa herba yang berasal dari kawasan Asia Tenggara tetapi penyebarannya telah hampir merata di seluruh dunia. Tanaman pisang dapat dimanfaatkan secara luas oleh masyarakat Indonesia karena beragam manfaat yang dimilikinya (Triyono, 2010).

Salah satu penyakit pada tanaman pisang yaitu penyakit layu yang disebabkan oleh bakteri. Penyebab penyakit layu bakteri pada pisang ini dikenal dengan berbagai nama antara lain Pseudomonas celebensis (Hartati dkk., 1989 dalam Suharjo dkk., 2008), Blood Disease Bacterium (Eden-Green, 1994), Ralstonia sp. (Mujim dkk., 1999 dalam Aeny, 2001), Ralstonia haywardii (Remenant dkk., 2011 dalam CABI 2016) dan Ralstonia syzygii subsp. celebensis (Safni dkk., 2014). Menurut Aeny dkk. (2007), penyakit layu bakeri pisang memiliki gejala yang ditunjukkan dengan menguningnya daun ketiga atau keempat yang kemudian menyebabkan seluruh daunnya kering dan akhirnya tanaman mati. Bagian dalam buah tampak berwarna coklat kehitaman disertai cairan agak kental yang berwarna coklat kekuningan. Apabila dibuat potongan melintang bagian batang, maka akan terlihat adanya perubahan warna kecoklat-coklatan pada batang aslinya dan setelah beberapa saat akan muncul eksudat bakteri berwarna putih kotor atau coklat kehitaman pada permukaan irisan.

Saat ini, upaya pengendalian penyakit layu bakteri sudah banyak dilakukan termasuk penggunaan bahan kimia yang ternyata menimbulkan dampak negatif bagi lingkungan. Untuk mengatasi masalah tersebut maka perlu alternatif pengendalian yang efektif dan ramah lingkungan, misalnya penggunaan pestisida nabati (Trisnadi, 2016). Beberapa tanaman yang telah diteliti sebagai pestisida nabati antara lain adalah gulma siam (Chromolaena odorata) (Ulpa, 2008), kemuning (Murraya paniculata) (Raharja dkk., 2004) dan saliara (Lantana camara) (Lestari dkk., 2013).

Menurut Dharmautama (2014) selain konsentrasi, tingkat toksisitas pestisida nabati juga dipengaruhi oleh lama perendaman bahan tanaman. Tetapi belum diketahui pengaruh lama perendaman ekstrak gulma siam, kemuning dan saliara dalam mengendalikan patogen layu bakteri (Blood Disease Bacterium). 
Penelitian ini bertujuan untuk mengetahui pengaruh lama perendaman dan taraf konsentrasi ekstrak gulma siam, kemuning dan saliara terhadap penghambatan pertumbuhan Blood Disease Bacterium secara in vitro dan mengetahui interaksi antara lama perendaman dan taraf konsentrasi ekstrak gulma siam, kemuning dan saliara terhadap penghambatan pertumbuhan Blood Disease Bacterium secara in vitro.

\section{BAHAN DAN METODE}

Penelitian ini dilakukan di Laboratorium Bioteknologi Fakultas Pertanian Universitas Lampung. Pelaksanaan penelitian dimulai dari Maret 2016 hingga Juli 2016. Pada penelitian ini dilakukan penyiapan isolat Blood Disease Bacterium (BDB), penyiapan ekstrak gulma siam ( $C$. odorata), kemuning ( $M$. paniculata) dan Saliara (L. camara), penyiapan medium berisi Blood Disease Bacterium , pengujian penghambatan ekstrak gulma siam, kemuning dan saliara terhadap pertumbuhan Blood Disease Bacterium secara in vitro serta pengamatan dan pengumpulan data.

Penelitian terdiri dari tiga subpercobaan. Pada masing-masing subpercobaan perlakuan disusun menggunakan Rancangan Acak Lengkap (RAL) dalam faktorial, dengan empat ulangan. Faktor pertama adalah lama perendaman dan faktor kedua yaitu tingkat konsentrasi. Data yang diperoleh diuji dengan analisis ragam dan nilai tengah antar perlakuan diuji dengan uji Beda Nyata Terkecil (BNT) pada taraf 5\%.

Isolat Blood Disease Bacterium diperoleh dengan cara mengisolasi patogen dari buah pisang yang terinfeksi dari daerah Gedung Meneng, Bandar Lampung. Setelah itu dilakukan uji hipersensitif pada daun tembakau dan uji patogenisitas pada bibit pisang terhadap bakteri yang diduga Blood Disease Bacterium. Uji hipersensitif dilakukan dengan cara menginjeksikan suspensi bakteri yang sebelumnya telah diisolasi dari pisang yang terserang layu bakteri ke daun tembakau (Wahyudi dkk., 2011). Uji patogenisitas pada bibit pisang berumur 3 bulan yang dilakukan dengan cara merendam akar tanaman pisang dalam suspensi bakteri patogen selama 15 menit. Kemudian tanaman pisang ditanam lagi pada polybag dan sisa suspensi disiramkan di sekitar tanaman pisang (Devi dkk., 2013).

Ekstrak gulma siam diambil dari bagian bunga, kemuning dan saliara diambil dari bagian daun masingmasing sebanyak 100 gram. Kemudian, masing-masing bagian tanaman dirajang lalu direndam dalam air sebanyak $100 \mathrm{ml}$ selama 0, 12 dan 24 jam. Selanjutnya, bagian tanaman yang telah direndam, dihaluskan dengan mortar dan disaring dengan kain sifon. Tingkat konsentrasi yang digunakan untuk ekstrak kemuning yaitu $35 \%, 40 \%, 45 \%, 50 \%, 55 \%$, ekstrak gulma siam yaitu $65 \%, 70 \%, 75 \%, 80 \%$ dan $85 \%$ dan ekstrak saliara yaitu $75 \%, 80 \%, 85 \%, 90 \%$ dan $95 \%$.

Penyiapan medium BDB dilakukan dengan cara mengambil 1 tabung reaksi biakan murni BDB dan dimasukkan dalam $5 \mathrm{ml}$ air steril lalu dihomogenkan dengan rotamixer. Selanjutnya $5 \mathrm{ml}$ suspensi ditambahkan dalam $100 \mathrm{ml}$ media NA kemudian dicampur dan diratakan serta dituang ke dalam cawan petri sebanyak $\pm 10 \mathrm{ml}$ per cawan.

Pengujian penghambatan ekstrak gulma siam, kemuning dan saliara terhadap pertumbuhan Blood Disease Bacterium secara in vitro dilakukan dengan menggunakan metode difusi agar. Potongan cakram kertas saring berdiameter $0,5 \mathrm{~cm}$ direndam dalam ekstrak gulma siam, kemuning dan saliara sesuai dengan konsentrasi perlakuan selama 2 menit agar meresap sampai jenuh. Kemudian, cakram kertas yang telah direndam tersebut ditiriskan lalu diletakkan pada media NA yang sebelumnya telah dicampur dengan biakan BDB.

Pengamatan dan pengumpulan data dilakukan pada ketiga subpercobaan untuk mengukur diameter zona penghambatan yang terbentuk di sekeliling cakram kertas. Pengamatan dilakukan selama 24 jam. Zona penghambatan ditandai dengan adanya daerah bening di sekitar potongan kertas saring.

\section{HASIL DAN PEMBAHASAN}

\section{Reaksi Hipersensitif Tanaman Tembakau}

Berdasarkan uji hipersensitif yang telah dilakukan diketahui bahwa bakteri yang telah diinjeksikan tersebut menimbulkan reaksi hipersensitif pada daun tembakau yang ditunjukan dengan adanya gejala nekrotik yang terjadi pada daun tanaman tembakau. Gejala yang terlihat pada daun tembakau dimulai dengan terjadinya klorosis 1 hari setelah inokulasi (Gambar 1a) dan nekrosis yang terjadi sekitar 15 hari setelah inokulasi (Gambar $1 b)$.

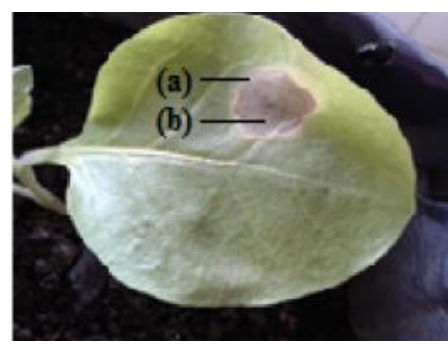

Gambar 1. Gejala klorosis dan nekrosis pada daun tembakau : 1 hari setelah inokulasi (a) dan 15 hari setelah inokulasi (b) 


\section{Uji Patogenisitas pada Tanaman Pisang}

Berdasarkan hasil pengamatan diketahui bahwa tanaman pisang yang telah diinokulasi menampakkan gejala layu bakteri pisang. Pada awalnya daun layu dan menguning yang dimulai dari titik tumbuh kemudian terjadi nekrosis atau kematian jaringan (Gambar 2).

Pengaruh Aplikasi Ekstrak Gulma Siam ( $C$. odorata) terhadap Penghambatan Pertumbuhan Blood Disease Bacterium secara In vitro

Tidak terdapat interaksi antara lama perendaman dengan tingkat konsentrasi ekstrak gulma siam dalam mempengaruhi penghambatan pertumbuhan Blood Disease Bacterium. Semua tingkat konsentrasi dapat meningkatkan zona penghambatan dan konsentrasi $85 \%$ mempunyai diameter zona penghambatan yang tertinggi (Tabel 1). Lama perendaman tidak berpengaruh nyata terhadap diameter zona penghambatan Blood Disease Bacterium (Tabel 2).

Pengaruh Aplikasi Ekstrak Kemuning ( $M$. paniculata) terhadap Penghambatan Pertumbuhan Blood Disease Bacterium secara In vitro

Terdapat interaksi antara lama perendaman dengan konsentrasi ekstrak kemuning dalam menghambat pertumbuhan Blood Disease Bacterium. Pada perlakuan lama perendaman selama 24 jam dan 12 jam konsentrasi $55 \%$ cenderung paling menghambat pertumbuhan Blood Disease Bacterium (Tabel 3). Pada perlakuan tanpa perendaman (24 jam) tingkat konsentrasi $45 \%$ mempunyai diameter penghambatan yang paling besar tetapi tidak berbeda nyata dengan tingkat konsentrasi 50\% dan 55\% (Tabel 3).

Pengaruh Aplikasi Ekstrak Saliara (L. camara) terhadap Pertumbuhan Blood Disease Bacterium secara In vitro

Lama perendaman tidak berpengaruh nyata terhadap diameter zona penghambatan Blood Disease Bacterium (Tabel 5). Tidak terdapat interaksi antara lama perendaman dengan konsentrasi ekstrak saliara dalam mempengaruhi penghambatan pertumbuhan Blood Disease Bacterium. Semua tingkat konsentrasi dapat meningkatkan zona penghambatan dan konsentrasi 95\% mempunyai diameter zona penghambatan yang tertinggi (Tabel 4).

Senyawa khas yang terdapat pada bunga gulma siam yaitu flavonoid (Collinz dan Franzblau, 1997 dalam Ulpa, 2008). Senyawa flavonoid dilaporkan dapat bersifat sebagai koagulator protein. Protein yang mengalami koagulasi akan nonfungsi menyebabkan kerusakan dinding sel bakteri (Sulastrianah dkk., 2014). Selain itu, flavonoid juga bekerja langsung pada membran

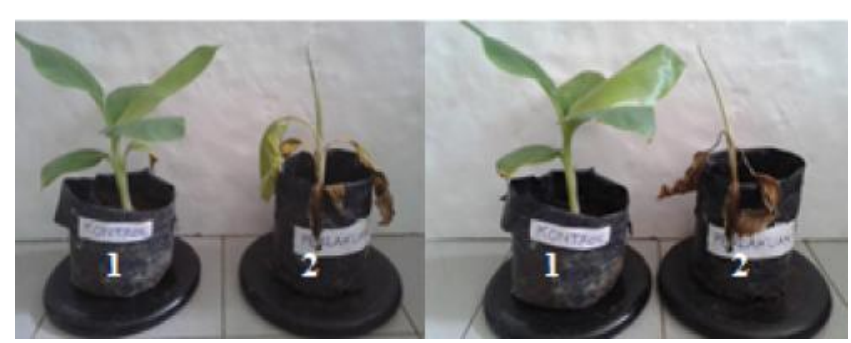

Gambar 2. Hasil inokulasi tanaman pisang : 7 hari setelah inokulasi (a2) dan 14 hari setelah inokulasi (b2) dan kontrol (a1 \& b1)

Tabel 1. Pengaruh taraf konsentrasi ekstrak gulma siam terhadap diameter zona penghambatan pertumbuhan BDB

\begin{tabular}{cc}
\hline Konsentrasi (\%) & $\begin{array}{c}\text { Diameter zona } \\
\text { penghambatan }(\mathrm{mm})\end{array}$ \\
\hline 0 & $0,0 \mathrm{c}$ \\
65 & $4,48 \mathrm{~b}$ \\
70 & $5,44 \mathrm{ab}$ \\
75 & $5,52 \mathrm{ab}$ \\
80 & $5,96 \mathrm{a}$ \\
85 & $6,40 \mathrm{a}$ \\
\hline
\end{tabular}

BNT $(0,05)$

0,31

Keterangan: Angka yang diikuti oleh huruf yang sama dalam satu kolom tidak berbeda nyata pada uji BNT 5\%.

Tabel 2. Pengaruh lama perendaman bunga gulma siam terhadap diameter zona penghambatan pertumbuhan BDB

\begin{tabular}{cc}
\hline $\begin{array}{c}\text { Lama perendaman } \\
\text { (jam) }\end{array}$ & $\begin{array}{c}\text { Diameter zona } \\
\text { penghambatan }(\mathrm{mm})\end{array}$ \\
\hline 0 & 4,39 \\
12 & 5,23 \\
24 & 4,28 \\
\hline
\end{tabular}

barier sel bakteri yang menyebabkan kebocoran sel (Lamb, 2005).

Senyawa yang khas terdapat pada daun kemuning antara lain terpenoid dan flavonoid (Dosoky, 2016). Senyawa yang dapat larut dalam air yaitu flavonoid. Menurut Arteel dan Sies (1999), senyawa flavonoid memiliki sifat khas pelarut organik, mudah terurai pada temperatur tinggi dan dapat larut dalam air. Flavonoid bekerja langsung pada membran barier sel bakteri yang menyebabkan kebocoran sel (Lamb, 2005).

Terpenoid umumnya larut dalam pelarut organik dan tidak larut dalam air (Ketaren 1987 dalam Ikawaty, 
Tabel 3. Pengaruh lama perendaman dan taraf konsentrasi ekstrak daun kemuning terhadap penghambatan pertumbuhan BDB

\begin{tabular}{ccc}
\hline $\begin{array}{c}\text { Lama } \\
\text { perendaman } \\
\text { (jam) }\end{array}$ & Konsentrasi (\%) & $\begin{array}{c}\text { Diameter zona } \\
\text { penghambatan } \\
(\mathrm{mm})\end{array}$ \\
\hline 0 & 0 & $0,00 \mathrm{e}$ \\
& 35 & $0,00 \mathrm{e}$ \\
& 40 & $0,00 \mathrm{e}$ \\
& 45 & $0,00 \mathrm{e}$ \\
& 50 & $5,13 \mathrm{a}$ \\
12 & 55 & $4,88 \mathrm{ab}$ \\
\hline & 0 & $0,00 \mathrm{e}$ \\
& 35 & $1,25 \mathrm{de}$ \\
& 40 & $0,00 \mathrm{e}$ \\
& 45 & $2,94 \mathrm{~cd}$ \\
& 50 & $4,88 \mathrm{ab}$ \\
& 55 & $6,06 \mathrm{a}$ \\
\hline & 0 & $0.00 \mathrm{e}$ \\
& 35 & $3,19 \mathrm{bc}$ \\
& 40 & $3,13 \mathrm{bcd}$ \\
& 45 & $5,50 \mathrm{a}$ \\
& 50 & $5,13 \mathrm{a}$ \\
& 55 & $6,44 \mathrm{a}$ \\
\hline BNT $(0,05)$ & & 0,59 \\
\hline
\end{tabular}

Keterangan: Angka yang diikuti oleh huruf yang sama dalam satu kolom tidak berbeda nyata pada uji BNT 5\%.

2015). Terpenoid mempunyai sifat anti bakteri yaitu bereaksi dengan porin pada membran luar dinding sel bakteri, membentuk ikatan polimer yang kuat sehingga mengakibatkan rusaknya porin. Rusaknya porin yang merupakan pintu keluar masuknya senyawa akan mengurangi permeabilitas dinding sel bakteri (Sulastrianah dkk., 2014). Dengan demikian, diantara kedua senyawa aktif hanya salah satu senyawa yang bekerja dalam menghambat bakteri Blood Disease Bacterium yaitu flavonoid.

Daun saliara memiliki senyawa yang khas antara lain tanin, terpenoid dan flavonoid (Novianti, 2013). Senyawa kimia yang dapat larut dalam air dari ketiga senyawa tersebut antara lain tanin dan flavonoid. Tanin dapat larut dalam air dan apabila dilarutkan dalam air panas kelarutannya akan bertambah besar (Rozanna dan Silvia, 2014). Sedangkan flavonoid mudah terurai pada temperatur tinggi dan dapat larut dalam air (Arteel dan Sies,1999). Senyawa flavonoid diduga menyebabkan terjadinya kerusakan permeabilitas dinding sel bakteri,
Tabel 4. Pengaruh taraf konsentrasi ekstrak saliara terhadap diameter zona penghambatan pertumbuhan BDB

\begin{tabular}{cc}
\hline Konsentrasi (\%) & $\begin{array}{c}\text { Diameter zona } \\
\text { penghambatan }(\mathrm{mm})\end{array}$ \\
\hline 0 & $0,00 \mathrm{e}$ \\
75 & $2,81 \mathrm{~d}$ \\
80 & $2,79 \mathrm{~d}$ \\
85 & $3,44 \mathrm{c}$ \\
90 & $3,92 \mathrm{~b}$ \\
95 & $4,25 \mathrm{a}$ \\
\hline BNT $(0,05)$ & 0,08 \\
\hline
\end{tabular}

Keterangan: Angka yang diikuti oleh huruf yang sama dalam satu kolom tidak berbeda nyata pada uji BNT 5\%.

Tabel 5. Pengaruh lama perendaman daun saliara terhadap diameter zona penghambatan pertumbuhan BDB

\begin{tabular}{cc}
\hline $\begin{array}{c}\text { Lama perendaman } \\
\text { (jam) }\end{array}$ & $\begin{array}{c}\text { Diameter zona } \\
\text { penghambatan }(\mathrm{mm})\end{array}$ \\
\hline 0 & 2,99 \\
12 & 2,74 \\
24 & 2,88 \\
\hline
\end{tabular}

mikrosom, dan lisosom sebagai hasil interaksi antara flavonoid dengan DNA bakteri. Kemudian senyawa tanin diduga berhubungan dengan kemampuannya dalam menginaktivasi adhesin mikroba, enzim, dan protein transport pada membran sel (Novianti, 2013). Kedua senyawa inilah yang diduga menghambat pertumbuhan Blood Disease Bacterium.

\section{KESIMPULAN}

Simpulan yang diperoleh berdasarkan penelitian yang dilakukan yaitu pada percobaan dengan ekstrak gulma siam, interaksi antara lama perendaman dan tingkat konsentrasi tidak berpengaruh nyata terhadap penghambatan pertumbuhan BDB secara in vitro. Lama perendaman juga tidak meningkatkan penghambatan, sedangkan tingkat konsentrasi secara nyata meningkatkan penghambatan. Tingkat konsentrasi $85 \%$ sudah efektif menekan pertumbuhan BDB secara in vitro.

Pada percobaan dengan ekstrak daun kemuning, faktor lama perendaman berinteraksi secara nyata dengan faktor tingkat konsentrasi dalam meningkatkan 
penghambatan pertumbuhan BDB. Tingkat konsentrasi $45 \%$ sudah efektif menekan pertumbuhan BDB secara in vitro.

Pada percobaan dengan ekstrak saliara, interaksi antara lama perendaman dan tingkat konsentrasi tidak berpengaruh nyata terhadap penghambatan pertumbuhan BDB secara in vitro. Lama perendaman juga tidak meningkatkan penghambatan, sedangkan tingkat konsentrasi secara nyata meningkatkan penghambatan. Tingkat konsentrasi $95 \%$ sudah efektif menekan pertumbuhan BDB secara in vitro.

\section{DAFTAR PUSTAKA}

Aeny, T. N. 2001. Patogenisitas bakteri layu pisang (Ralstonia sp.) pada beberapa tanaman lain. J. HPT Tropika. 1 (2): 60-62.

Aeny, T. N., R. Suharjo, dan S. Mujim. 2007. Skrining bakteri antagonis Ralstonia sp. penyebab penyakit layu bakteri pisang di Lampung. J. HPT Tropika 7 (2): 100-110.

Arteel G.E. dan H. Sies. 1999. Protection against peroxynitrite by cocoa polyphenol oligomers. FEBS Letters. 462: 167-170

CABI. 2016. Ralstonia solanacearum (bacterial wilt of potato). http://www.cabi.org/isc/datasheet/ 45009, [10 Februari 2015].

Dharmautama, M., M. Edi, dan S.A. Mardi. 2014. Pertumbuhan Bakteri Plak dan Candida Albicans Pada Basis Gigi Tiruan Lepasan Akrilik Setelah Perendaman dalam Infusa Bunga Rosella. Research Report. Dipublikasikan oleh Bagian Prostodonsia Fakultas Kedokteran Gigi.Universitas Hasanuddin. Makassar. Devi, R.K., L.Q. Aini, dan A.L. Abadi. 2013. Uji metode inokulasi dan patogenisitas Blood Disease Bacterium (BDB) pada buah pisang (Musa sp.). Jurnal HPT. 1(1): 40-46.

Dosoky, N.S., P. Satyal, T.P. Gautam, dan W.N. Setzer. 2016. Composition and biological activities of Murraya paniculata (L.) jack essential oil from Nepal. Articles Medicines. 3(7): 1-10.

Edeen-green, S.J. 1994. Banana Blood Disease. Parc Scientifique Agropolis. France.

Ikawaty, A. L. 2015. Ekstraksi minyak atsiri bunga krisan (Chrysanthemum cinerariaefolium) dengan pelarut etanol dan n-heksana. Tugas Akhir. Universitas Negeri Semarang. Semarang. hlm: 1-23.
Lamb, A. J. 2005. Antimicrobial activity of flavonoids. International Journal of Antimicrobial Agents. 26: 343-356.

Lestari, A., M. Jamhari, dan I.N. Kundera. 2013. Daya hambat ekstrak daun tembelek (Lantana camara L.) terhadap pertumbuhan bakteri Escherichia coli. e-Jipbiol. 1: 42-49.

Novianti. 2013. Aktivitas antibakteri ekstrak etanol daun tembelekan (Lantana camara L.) terhadap Staphylococcus aureus dan Escherichia coli dengan metode mikrodilusi CLSIM07-A9. Jurnal Ilmiah Farmako Bahari 4(2): 5-15.

Raharja, F., Rosnaeni, dan D. Wardani. 2004. Uji Aktivitas Antibakteri Ekstrak Etanol Daun Kemuning (Murraya Paniculata (L.) Jack) terhadap Pertumbuhan Escherichia coli secara In Vitro. Bagian Mikrobiologi dan Farmakologi Fakultas Kedokteran. Universitas Kristen Maranatha.

Rozanna, S.I. dan R.Y. Silvia. 2014. Pengaruh perbandingan pelarut etanol-air terhadap kadar tanin pada sokletasi daun gambir (Uncaria gambir Roxb). SAGU. 13(1): 1-7.

Safni, I., Ilse, C., Paul, D.V., Mark, F., Lindsay, S. and Ulrike, K. 2014. Polyphasic taxonomic revision of the Ralstonia solanacearum species complex. International Journal of Systematic and Evolutionary Microbiology 64: 3087-3103.

Suharjo, R., S. Subandiyah, dan E. Martono. 2008. Hubungan antara kedatangan frekuensi imago Erionata thrax pada bunga pisang dan keterjadian penyakit layu bakteri pisang pada lahan sawah, tegalan dan pekarangan. J. HPT Tropika. 8(1): 47-54.

Sulastrianah, Imran, dan Fitria E.S. 2014. Uji Daya Hambat Ekstrak Daun Sirsak (Annona muricata L.) dan Daun Sirih (Piper betle L.) terhadap Pertumbuhan Bakteri Escherichia coli. Bagian Farmakologi FK UHO. Kendari. Sulawesi Tenggara.

Trisnadi, R. 2016. Pestisida Ramah Lingkungan Untuk Mengendalikan Hama dan Penyakit Tanaman. Dinas Perkebunan dan Kehutanan. Probolinggo.

Triyono, A. 2010. Pengaruh konsentrasi ragi terhadap karakteristik sari buah dari beberapa varietas pisang (Musa paradisiaca L.). Prosiding Seminar Nasional Teknik Kimia "Kejuangan" 
26 Januari. Balai Besar Penggunaan Teknologi Tepat Guna. Yogyakarta. Hlm: 1-7.

Ulpa, M. 2008. Studi habitat dan pengujian ekstrak gulma siam (Chromolaena odorata) dalam menghambat pertumbuhan bakteri penyebab penyakit layu pisang (Ralstonia sp.) secara in vitro. Skripsi. Universitas Lampung. Bandar Lampung. Hlm: 1-45.
Wahyudi, A.T., S. Meliah, dan A.A. Nawangsih. 2011. Xanthomonas oryzae pv. oryzae bakteri penyebab hawar daun ada padi: isolasi, karakterisasi, dan telaah mutagenesis dengan transposon. MAKARA. 15(1): 89-96. 